\title{
Sex and dominance behavior in the rat
}

\author{
EDWARD T. UYENO and MARGARET WHITE, Stanford \\ Research Institute, Menlo Park, Calif. 94025
}

Twenty male rats competed against 20 females under survival motivation. In each pair (male ys female) the competitor that forced its opponent back to escape from the underwater tube was considered to be the dominant one of the pair. Nine males and 10 females were dominant. indicating that in the survival competition the males and females do not differ significantly in dominance behalior. The results are in accord with those of Warren \& Maroney (1958) who reported that dominance behavior of the rhesus monkey is not related to sex.

Some studies have demonstrated that males are more aggressive and dominant than females; for example. Hartup \& Himeno (1959) reported that boys are more aggressive in doll-play than girls. Also Muste \& Sharpe (1947) found that preschool boys are more dominant than girls. Buss \& Durkee (1958) found that male college students produce more intensely hostile responses than females in a learning experiment. Fredericson (1949. 1952) reported that male mice are more aggressive than females. However, Warren \& Maroney (1958) found that aggressiveness and dominance behavior in rhesus monkeys are not related to sex.

The present study was designed to determine the effect of sex on dominance behavior of rats competing under more demanding and stringent conditions than in the previous studies. More specifically, dominance behavior was evaluated by a procedure in which pairs of animals competed under survival motivation to escape from an underwater swim tube. METHOD

\section{Subjects}

Twenty male and 20 female rats of the Wistar strain weighing 170 to $190 \mathrm{~g}$ at the beginning of the experiment were housed individually. Most of the animals were fed ad libitum: but a few males were maintained on a feeding schedule so that their weights would be approximately equal to those of their female opponents.

Apparatus

The dominance tests were conducted in an underwater swim tube. The 4-ft plastic tube. $2 \mathrm{in.}$ in diameter. wals placed horizontally in at $51 / 2-\mathrm{ft} \times 1-\mathrm{ft} \times 1 / 2-\mathrm{ft}$ tank and submerged in $3^{1 / 2}$ in. of water at $22 \mathrm{deg}$ ( (Uyeno \& White. 1967). A rat weighing 170 to $220 \mathrm{gm}$ could swim through it. but could not turn around in it nor pass another rat swimming in the opposite direction. Two detachable start tubes. One at each end of the swin tube, were used.

Procedure

In the first pretraining trial the animals were placed one at a time in a start tube. and were partly submerged at one end of a half-submerged 27-in. swim tube. As the start door was raised they were allowed to traverso through the tube and escape at the other end. They were never allowed to escape from the starting point. On the second pretraining trial they were completely submerged and forcel to swim through the fully submerged 27 -in. tube to escape. On all trials after the second pretraining trial. the animals were fully submerged and forced to swim through a completely submerged 4-it tube. On the third pretraining trial. the time taken to swim the long tube was measured in seconds with a stop watch. On the basis of their swimming times, the 20 males were matched and assigned to two groups of equal size. Group 1 swam from the right to the left end of the tube during the 12 training trials. and Group 2 swam from left to right. Similarly. the 20 females were matched and assigned to two groups. The Group 1 females swam in the opposite direction from that of the Group 1 males; the Group 2 females swam in the opposite direction from that of the Group 2 males. Two trials were given daily, allowing $3 \mathrm{~h}$ between the first and second daily trials. The time taken to swim through the tube was recorded.

On the basis of the swimming time on the last four training trials, the males in Group 1 were ranked. Similarly, the females in Group I were ranked. Each male was paired with a lemale with a similar rank. Likewise, the Group 2 males were ranked and paired with the Group 2 females with similar ranks.

In the survival competition situation, a male rat was placed in a start tube, and its matched female opponent was put in the start tube at the opposite end of the 4-ft tube. Both were submerged simultancously. The start doors were lifted to allow them to swim toward their "escape ends." As they approached each other, the rat that forced its opponent to move backward to the opponent's starting point was scored as "dominant."

\section{RESULTS AND DISCUSSION}

Nine males and 10 females were dominant. This difference was not statistically significant, indicating that male and female rats are equally dominant. The mean swimming time of the males was not significantly different from that of the females. Moreover, dominance measure was not significantly correlated with weight.

The results are consistent with those of Warren \& Maroney (1958), who found that dominance behavior of the rhesus monkey is not related to sex. The difference between the present finding and those of Fredericson $(1949,1952)$ with mice may be attributable to differences in the species or in the method of assessing dominance. In his spontaneous fighting study, males were not pitted against females; males were pitted against males. and females against females.

The fact that human females are less dominant than males (Hartup \& Himeno, 1959: Muste \& Sharpe. 1947) may be due. as Buss and Durkee (1968) have suggested, to cultural training that discourages females from taking dominant roles in the presence of males. However, if they are forced to compete with males under survival motivation, they may be as dominant as males.

\section{REFERENCES}

BUSS, A. H., \& DURKFF, A. Conditioning of hostile verbalizations in a situation resembling a clinical interview. Journal of Consulting Psychology, 1958. 22.415-418.

FREDFRICSON, E. Response litency and habit strength in relationship to spontaneous fighting in ( 57 black mice. Anatomical Record, 1949, $105,2 \%$.

FRFDERICSON, E. Aggressiveness in female mice. Journal of Comparative \& Physiological Psychology, 1952, 45 . 254-257.

HARTUP. W. W., \& HIMENO. Y. Social isolation vs interaction with adults in relation to aggression in preschool children. Joumal of Abnormal \& Social Psychology, 1959, 59, 17-22.

MUSTF. M. J., \& SHARPE, D. F. Some influential factors in the determination of aggressive behavior in preschool children. Joumal of Child Development, 1947, 18, 11-28.

SIEGEL. S. Nonparametric statistics for the behavioral scitences. New York: McGraw-Hill Book Co., Inc.. 1956.

UYENO, L. T., \& WHITE, M. Social isolation and dominance behavior Journal of Comparative \& Physiological P'sychology. 1967, 6.3 157-159.

WARREN, J. M.. \& MARONEY, R. J. Competitive social interaction between monkeys. Journal of Social Psychology. 1958, +8. 223-23.3. NOTI:

1. This work was supported by Inited States Public Health Service Grant MH-06655 from the National Institute of Mental Health. 